\title{
Inflation and Taxes: Disincentives for Capital Formation
}

\author{
JOHN A. TATOM and JAMES E. TURLEY
}

\begin{abstract}
繁 $\mathrm{NE}$ of the disappointing features of the current expansion has been the sluggish growth of business investment spending. Businesses appear to be more reluctant to make outlays for purchases of new plant and equipment than was the case in previous periods of economic growth. Since the beginning of the current expansion in early 1975 , investment expenditures have grown at a 9.4 percent annual rate, compared to an average 11.8 percent rate for comparable periods in the four previous recoveries. ${ }^{ \pm}$When these dollar outlays are measured in terms of their purchasing power, the differential is even greater: real business investment in plant and equipment has grown at only a 3.7 percent rate during the current expansion, compared to a 7.8 percent average rate in previous expansions.
\end{abstract}

Numerous factors have been suggested as explanations for this relatively sluggish growth in capital outlays, including the uncertainty over proposed changes in tax and energy policy, the higher replacement cost and lower productivity of capital goods due to higher energy costs since 1974, and general uncertainty about the economic consequences of a new Administration. One factor which has not received its rightful share of publicity, however, is the unusually rapid rate of inflation associated with the current expansion. Inflation, in conjunction with the accounting convention of recording transactions at their historical values, reduces the returns generated by investment projects. In addition, the combined effects of inflation and the personal income tax structure tend to drive up the cost of obtaining the funds necessary for a given capital investment program. Each of these adverse effects of inflation provides a disincentive to business investment. Thus, inflation should be high on the list of culprits responsible for the lackluster performance of business investment spending.

The postwar recovery beginning in the second quarter of 1958 is excluded since it did not last as long as the current expansion.

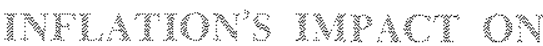

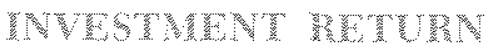

In order to discuss the effects of inflation on investment retum, it is useful to distinguish between nominal and real rates of retmin. Nominal measures refer to dollar amounts which use currently prevailing dollar prices as a yardstick. Real measures use a yardstick with a constant purchasing power of the dollar - the dollar value of goods and services is measured in terms of prices which prevailed in some previous or "base" period. In essence, real values measure the extent to which increases in nominal values actually reflect changes in the ability to purchase goods and services. An increase in income from $\$ 100$ to $\$ 120$ during a period when prices are rising by 5 percent per period involves a $\$ 20$ or 20 percent gain in nominal income. However, since this income will command only $\$ 15$ more in goods and services, real income has increased by only 15 percent.2 Since real measures are free of distortions produced by using a variable yardstick, real rates of return are examined below.

A series of examples illustrates the adverse impact of inflation on an investment project's real rate of return." The project remains the same in the following examples, but the annual rate of inflation over the life of the project is assumed to change from zero, to 5 , and then to 10 percent.

\footnotetext{
2This calculation of the real rate is found by subtracting the inflation rate over a period from the nominal rate of increase. The exact meastre of the real income gain in the example above provides a slightly different result. Since $\$ 120$ will buy only $\$ 114.29$ (\$120 $\% 1.05$ ) worth of goods and services, neasured in the initial period's prices, the real gan could be stated as the simple percentage gain of 14.3 percent.

BConsiderable work on this problem has been done by George Terborgh, Essays on Inflation (Washington, D.C. Machinery and Allied Products Institute and Council for Technological Advancement, 1971). Also see $T$. Nicolaus Tideman and Donald $P$. 'rucker, "The Tax Treat ment of Business Profits inder Inflationary Conditions," in Inflation and the Income Tax, ed, Henry f, Aaron (Washington, D.C.: The Brookings Institution, 1976$)$, pp. 33-74.
} 


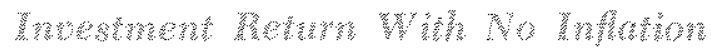

Suppose that a firm is considering the purchase of an asset which costs $\$ 300,000$ and is expected to yield an annual before-tax net cash income (the excess of cash receipts over cash expenses) of $\$ 100,000$ over its expected useful life of 5 years. ${ }^{4}$ The firm anticipates that the asset will have no value at the end of its useful life. To simplify the calculations, let the corporate income tax rate be 50 percent. Initially, it is assumed that inflation is nonexistent so that all dollar receipts and outlays over the expected life of the capital asset are also measures with constant purchasing power; any increase or decrease in dollar magnitudes implies a corresponding increase or decrease in the ability to purchase goods and services.

Table I indicates the annual cash flows associated with this project over its expected life. The first column depicts the annual before-tax net cash income of $\$ 100,000$ generated by the project. On this pretax basis, the inflows serve as a meastre of the benefits associated with the project itself, but do not represent a measure of the benefit which the firm will actually receive by acquiring this capital asset. To arrive at such a measure, corporate income taxes must be considered.

Corporate tax rates are intended to be levied on that portion of revenue which exceeds the total cost of operations over a particular period. To determine taxable income on this project, depreciation must be subtracted from the net cash receipts of Column I. Depreciation is the expense associated with the consumption, or wearing out, of a portion of a capital asset over any particular period. Under existing tax law, the firm is not allowed to deduct as an expense the cost of replacing the worn-out portion of the asset. Instead, it may only claim some portion of the original cost of the asset each year as an expense. Over time, total depreciation expenses cannot exceed the original cost of the asset.

The firm in the example is presumed to use straight-line depreciation, which means that an equal amount of the original cost is depreciated each year. Since the asset costs $\$ 300,000$, the annual depreciation charge (Column II) in each of the 5 years is $\$ 60,000$. By subtracting this amount from cash receipts in each period, taxable income is derived. The corporate tax

4To avoid problems associated with the measurement of income under the accrual method of accounting, it is assumed that all transactions occur on a cash basis. See Harold Bieman, Jr, and Seymour Smidt, The Capital Budgeting Decision, 4th ed. (New York: Macmillian Publishing Co., Inc., 1975), pp. 112-14.

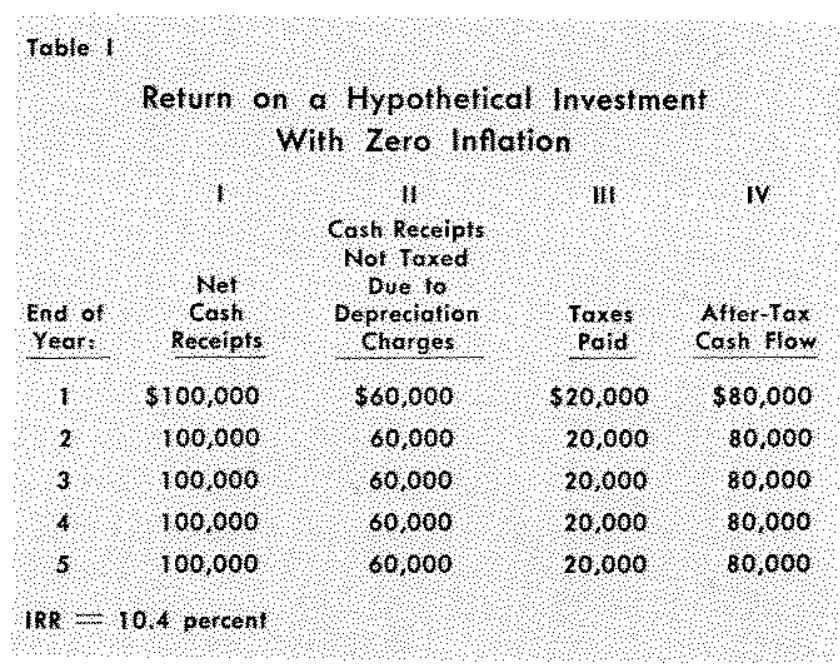

liability (Column III) is then determined by applying the corporate tax rate to taxable income. Subtracting this outflow of funds from net cash inflows (Column I), the net cash flow generated by the project and available to the firm is derived. These after-tax flows are shown in Column IV of Table I.

Given the initial cost of the asset, the after-tax flows in Column IV represent a rate of return of 10.4 percent per year. This rate of return may be compared to both the cost of obtaining investment funds (to determine whether or not to invest) and to the returns on alternative asset purchases (to determine how funds should be allocated). ${ }^{5}$

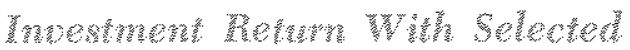

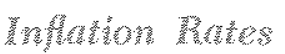

The project discussed above is now assumed to be generating a return in an environment where the price level is not stable, but rising at selected rates. A rising price level will affect the calculation of investment yield for two reasons. First, a given rate of inflation over the life of an asset will tend to be fully reflected in the pretax net cash receipts. That is, if all prices rise by 5 percent in any particular period, net cash receipts on the same units sold, in general, will

\footnotetext{
TThe rate of return on an investment here is the sinternal rate of return" (IRR). While the IRR can be used to compare the relative merits of alternative asset purchases, there are situations in which it may lead to an incorrect investment decision. In general, the net present value (NPV) model is preferred for evaluating investment projects. The IRR is used here only because it allows a simpler and more direct presentation of inflation's impact on investment retum. For a description and general discession of the IRR and NPV models, see J. Fred Weston and Eugene F. Brigham, Mana. gerial Finance, 5th ed. (Hinsdale, 1ll.: The Dryden Press, 1975), pp. 267-75, and Bieman and Smidt, The Capital Budgeting Decision, pp. 41-57.
} 


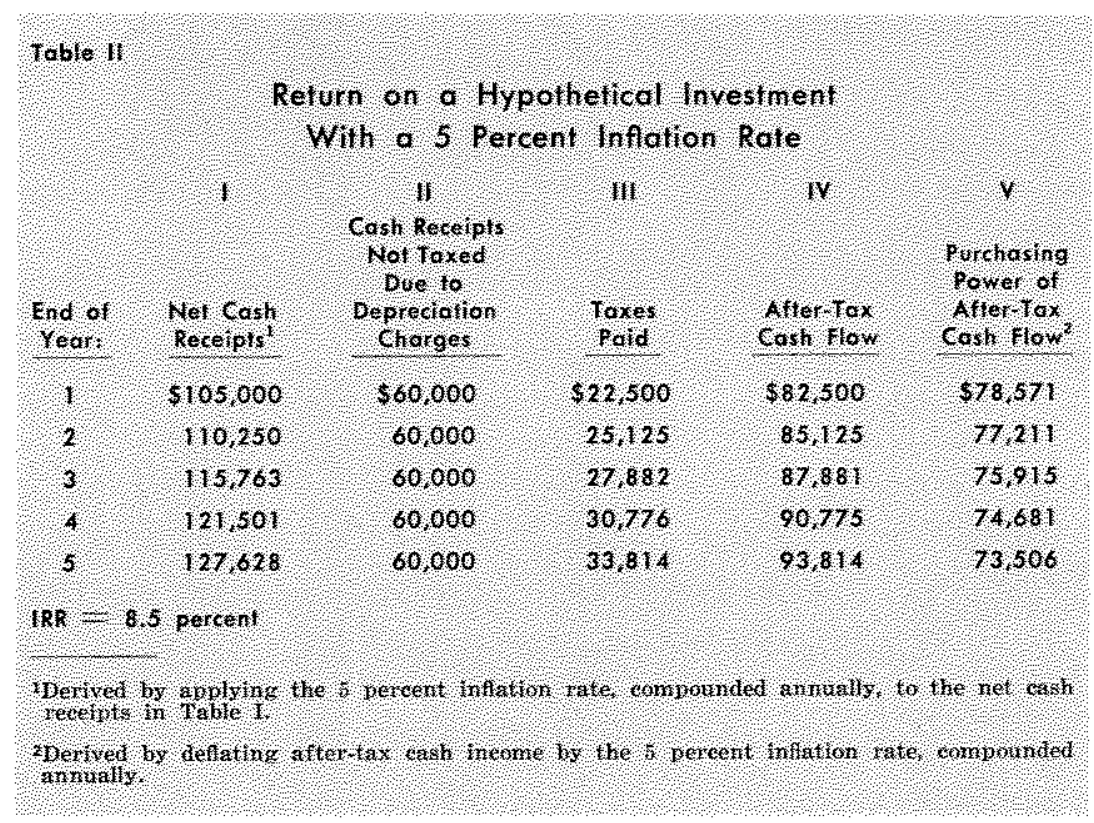

cent rate. This after-tax decline in the project's real return occurs even though the before-tax real yield remains unchanged.

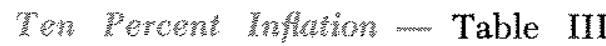
shows how an inflation rate of 10 percent per year over the asset's depreciable life affects the project's yield. Net cash receipts advance with the 10 percent inflation, rising from $\$ 110,000$ in year one to $\$ 161,051$ in year five: Again, in terms of the goods and services which can be purchased, these receipts are the same as those of the no-inflation example.

While the depreciation expenses remain the same, nominal taxes and income after taxes are greater than in the 5 percent inflation example. Once again, also rise by 5 percent. The second reason for recalculating investment return is due to the effect of inflation on the value of the after-tax dollar magnitudes generated each year. In the previous zero-inflation example, after-tax dollar flows (as well as pretax) represented real or constant-price magnitudes. In order to make comparisons with these real flows reported in Table $\mathrm{I}$, the effects of inflation on the aftertax dollar flows have to be removed.

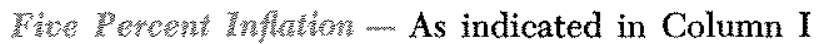
of Table II, the before-tax cash receipts increase by 5 percent in each year. Given this inflation boost, the incoming receipts in the prior example rise from $\$ 105,000$ after the first year of inflation to $\$ 127,628$ after the fifth year. Such inflated receipts, however, command no more goods and services than the receipts generated without inflation.

The dollar amount of net cash receipts which is not taxed because of depreciation charges remains the same as without inflation, since only $\$ 60,000$ per year is permitted for depreciation expense. Both taxable cash income and taxes paid are greater in each period because of the effects of inflation on the net cash receipts. The net result is that after-tax dollar inflows are greater than in the zero inflation example, but these receipts represent a diminished command over goods and services. This is indicated in Column $\mathrm{V}$ of Table II, which shows the after-tax cash inflows on a constant-dollar basis. A comparison of Tables I and II reveals that the real after-tax cash inflows are decreased by the inflation. Accordingly, the yield on this project is lowered 1.9 percentage points to an 8.5 pereven though the after-tax income reported in Column IV is increased, this rise in receipts is not sufficient to offset the general increase of prices which prevails over the project's life. Column $V$ shows that on a purchasing-power basis, the cash inflows are considerably lower than those in the previous examples. Accordingly, the yield on this project falls to a 6.9 percent rate-some 3.5 percentage points lower than the return on the project in a no-inflation environment.

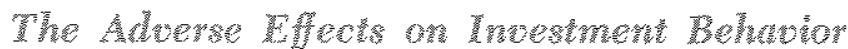

The source of the reduced real yield on investment is increased taxation associated with fixed nominal de preciation expenses. Even though the real value of cash inflows (before taxes) is insulated from the rate of inflation, the real value of the depreciation expense falls over time, and falls more as the inflation rate rises. This results in faster growth of taxable income - and the outllow of funds for taxes - than would be the case if depreciation expenses reflected the rising price level and replacement cost of capital. In effect, taxes are being levied not only on the income generated by the capital, but also on the capital itself. This taxation reduces the incentive of firms to invest. ${ }^{6}$

In response to such a disincentive, business firms would be expected to alter their behavior, primarily by reducing investment, in order to protect themselves

\footnotetext{
GFims may react by attempting to offset part of the lower yield associated with inflation-induced taxation by increasing the use of accelerated forms of depreciation, such as the "double declining balance" or the "sum-of-the-years-digits" method. However, the presence of an inflation effect is independent of the method of depreciation chosen.
} 


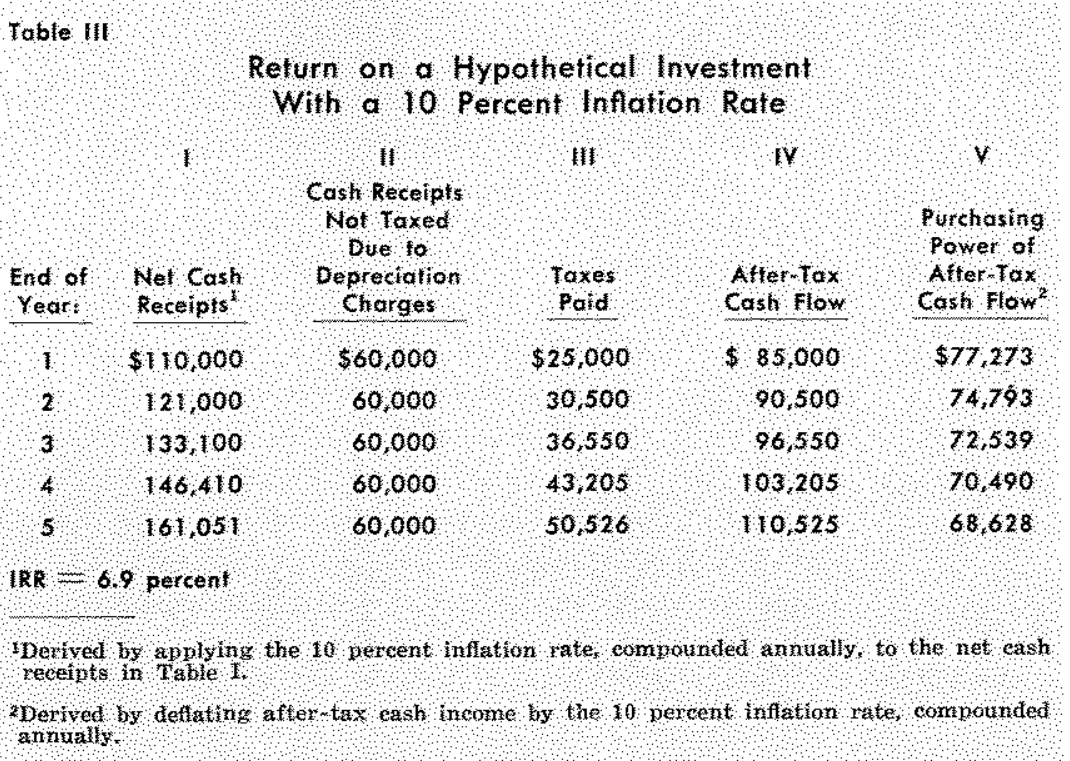

from the adverse effects of inflation. In addition, it is possible to show that the types of investment which firms undertake would be affected. For example, higher inflation rates discourage the adoption of capital intensive technologies, encourage the postponement of replacement investment, and typically discourage the purchase of capital assets with relatively long expected lives in favor of those with relatively short expected lives. ${ }^{7}$

Uncertainty about the future rate of inflation increases the riskiness of an expected income stream. Such riskiness reduces firms' incentives to acquire assets, given their real rate of return and the cost of funds. Recent evidence indicates that inflation uncertainty increases as the rate of inflation rises. ${ }^{8}$ Thus, a rise in the rate of inflation expected by firms not only reduces expected rates of return, it also increases risk which further reduces investment incentives and the demand for new capital assets.

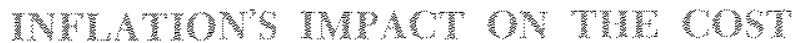

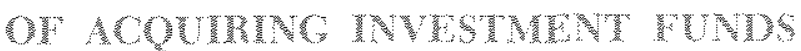

While inflation - operating through the tax system - serves to erode the rate of return on capital goods, it also has an adverse impact on the cost of acquiring investment funds. Again, the tax system plays a crucial role. Given the prevalling tax system, inflation raises

"See Charles R. Nelson, "Inflation and Capital Budgeting," Joumal of Finance (June 1976), pp. 923-31.

8See Beniamin Klein, "Our New Monetary Standard: The Measurement and Effects of Price Uncertainty, 1880-1973," Economic Inquiry (December 1975), pp. 461-84. the real market rate of interest demanded by individuals in order to supply funds through bond or new equity share purchases, or through retained earnings. ${ }^{9}$ The primary determinants of the cost of a given supply of investment funds are (1) the real yield required to induce the general public to forego current consumption in order to make new equity or borrowed funds available and (2) the personal tax treatment of the income received from owning stocks and bonds.

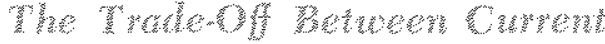

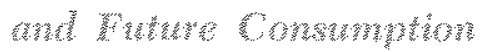

The first factor which influences the cost of investment funds depends upon individuals' decisions as to whether to direct a portion of current income to savings through, for example, the purchase of stocks and bonds, rather than to consumption. The saving decision involves the postponement of some current consumption for what is expected to be greater future consumption. The expected addition to future consumption opportunities is reflected in the yield obtained from holding stocks and bonds, which is most appropriately measured on a real after-tax basis.

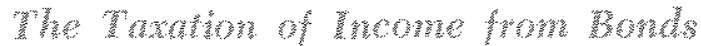 and works}

Two features of the U.S. tax system are of special importance in considering the effects of income taxes on the cost of investment funds for business. First, the taxation of income derived from holdings of stocks and bonds - whether in the form of stock dividends, capital gains, or interest income from bond ownership is based upon nominal, not real, income. ${ }^{10}$ Thus, inflation tends to increase personal taxes by inflating

9Martin Feldstein, Jerry Green, and Eytar Sheshinski, "Inflation and Taxes in a Growing Economy with Debt and Equity Finance," fortheoming in the Journal of Political Economy (April 1978), have fomally modeled most of the considerations discussed in this section. They concentrate on the effect of inflation on real net rates of return to investors assuming a fxed stock of capital and supply of funds, John Lintner, "Inflation and Security Returns," Journal of Finance (May 1975), pp. 259-80, cites statistical evidence uniformly showing that stockholders' net returns, both nominal and real, are negatively related to inlation rates. He also argues that the cost of funds to firms, including debt, may be positively related to inflation rates.

${ }^{10}$ Michael R. Darby, "The Financial and Tax Effects of Monetary Policy on Interest Rates." Economic Inquim (fune 1975), pp. 266-76, has explored some of the implications of personal income taxation for the effect of inflation on interest rates. 
nominal incomes, even if the purchasing power of the income payments remains the same. Such increased taxation is compounded by a second feature of the tax system - progressivity. As inflation raises the dollar incomes from almost all sources, it pushes taxpayers into higher "tax brackets," again regardless of whether the higher incomes represent an increased ability to buy goods and services or to pay taxes. ${ }^{11}$ Both features tend to reduce the purchasing power of income received from stocks and bonds. As a result, individuals will have less incentive to supply funds, and an increased incentive to consume now, unless they are compensated for the anticipated losses associated with increases in the inflation rate and inflationinduced taxation.

For example, suppose that in the absence of inflationary expectations and income tax considerations the typical individual is willing to save $\$ 1,000$ from current income to buy bonds yielding a 4 percent rate of return for one year. Individuals expect to be able to trade $\$ 1,000$ worth of current consumption goods for $\$ 1,040$ or 4 percent more of the same goods in a year. The anticipation of inflation does not change the evaluation of present consumption relative to future consumption - at a minimum, a 4 percent increase in the ability to purchase goods one year hence is still demanded. But, if prices are expected to rise over the year, a nominal yield of more than 4 percent is required if the demanded trade-off between current and future consumption is to be achieved.

If, for instance, prices are expected to rise by 5 percent, the dollar prices of future goods will be higher than at the time the bond was purchased. In order to be able to pay the higher prices, lenders will demand a higher nominal interest rate. The nominal yield required to induce individuals to forego $\$ 1,000$ worth of current consumption would have to rise to 9 percent in order to secure the minimum 4 percent real yield. ${ }^{12}$ In essence, individuals will demand the same real rate of return in the face of anticipated inflation; to secure this rate of return, ignoring personal income tax considerations, nominal interest rates must rise by an

\footnotetext{
11The erosion of real income due to infation in the presence of a progressive income tax is discussed by Nancy Janakoplos, "Paving More Taxes and Affording it Less," this Review (July 1975), pp. 9-13, and Leonall C. Andersen, "So What, it"s Only a Five Percent Infation" this Review (May 1977), pp. 21-23. While the explanation and examples there are in terms of labor income, the analysis for capital income is essentially the same.

12The exact nominal interest rate in this instance wonld have to be 9.2 percent in order to provide the 4 percent real rate of return. All of the nominal interest rates in this section are calculated by simply adding the rate of inflation to the corresponding real interest rate. See fn. 2 .
}

amount equal to the rise in the expected rate of inflation.

When personal income taxes are included, the effect on the nominal and real interest rates at which funds are supplied is more pronotnced. Suppose that the typical individual is in a 20 percent income tax bracket. In the zero-inflation case above, a market (nominal and real) rate of 5 percent on bonds is required in order to yield a 4 percent retum after taxes, since 20 percent of the interest income $(2 \times 5$ percent $=1$ percent) is taken by the taxing authority. With the 20 percent tax rate and a 5 percent yield on the bond, individuals are able to trade $\$ 1,000$ worth of current goods and services for $\$ 1,040$ or 4 percent more of the same goods and services in a year.

When inflation is expected to run at a 5 percent rate, a higher nominal interest rate on the same $\$ 1,000$ of lending is required in order to cover the higher prices in the future. In addition, individuals will face an enlarged tax burden in the future due to the higher nominal interest income. Thus, the nominal rate must rise by more than the increase in the anticipated inflation in order to assure a 4 percent real yield after personal taxes. Nominal interest income must rise enough to compensate for the effect of the inflation on the purchasing power of both the interest income and the initial funds supplied. Since taxes are levied on the nominal interest income, the interest return which is necessary to maintain the purchasing power of individuals' original capital is taxed as well. To compensate for this real tax burden on capital, taxpayers will demand a higher real market interest rate, before taxes, in order to supply the same funds.

In the example, the nominal market rate must rise from 5 percent (with no inflation and a 20 percent tax rate) to about 11.25 percent (with 5 percent inflation and a 20 percent tax rate) in order to provide the after-tax real yield of 4 percent to the individual. Of the interest income which accrues at a rate of about 11.25 percent per year, 20 percent must be paid in taxes $(.2 \times 11.25=2.25)$ so that the nominal after-tax yield is 9 percent. This is the rate required to yield a 4 percent real rate of return after taxes and to cover the 5 percent loss of purchasing power of the original $\$ 1,000$. The nominal market rate of 11.25 percent, together with a 5 percent inflation rate, implies that a pretax real market rate of 6.25 percent $(11.25-5$. percent) is required to make the bond attractive. Thus, the 5 percentage point rise in inflation raises the real market rate demanded by lenders from 5 percent to 6.25 percent. 
Since the personal income tax is progressive, higher nominal incomes associated with inflation can push taxpayers into higher tax brackets. Thus, a particular individual, initially in a 20 percent tax bracket, would require an even higher nominal return in order to compensate for this facet of the increased real tax burden. Since nominal interest rates rise by more than the 5 percent advance in the inflation rate in the example above, the real market rate must rise by more than 1.25 percentage points.

Since nominal dividend earnings as well as nominal capital gains are subject to personal income taxes, the required yield on stocks will be affected by anticipated inflation in the same manner as bonds. To supply the same dollar flow of funds, suppliers require compensation for both the anticipated inflation as well as the increased future tax liability which such a higher inflation rate would entail. Because the required nominal market yields on all supplies of funds rise by more than the increase in anticipated inflation, the real rates of interest which individuals require to supply a given amount of funds will rise. ${ }^{13}$

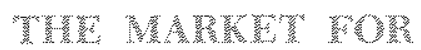 WNats}

Firms tend to make eapital investments when the expected real after-tax rate of return from an investment equals or exceeds the cost of acquiring the necessary funds. As has been shown, inflation has an adverse impact on both aspects of this criterion. Due to the implicit tax on capital emanating from historical cost depreciation, higher rates of inflation over the life of a project reduce the real after-tax rate of return on investment projects. Projects which would be marginally profitable, with a given cost of funds, become

13The real cost of funds to firms is also influenced by the corporate income tax treatment of the firm's payments of incone to funds suppliers. A firm's nominal interest pay. ments to bondholders are tax deductible expenses while dividend payments or capital gains which accrue through retained earnings are not tax deductible. When the infation rate is expected to rise, this differential tax treatment creates an incentive for firms to place greater emphasis on the lower cost of debt financing relative to equity. This point has been einphasized by "Tideman and Tucker, "The Tax Treatment of Business Profits under Inflationary Conditions."

Attitudes toward debt and its associated risk, however, limt the incentive to switch to debt. As debt becomes a greater proportion of a firm's desired financial structure, creditors and stockholders must be compensated for the increased riskiness of the firm. Thus, the cost of both sources of funds terads to rise by more than that suggested by inflation and tax considerations alone. A discussion of the effects of increased financial risk on a firm's cost of equity and debt may be found in Weston and Brigham, Managerial Finatice, pp. 604-12 and 636-57.

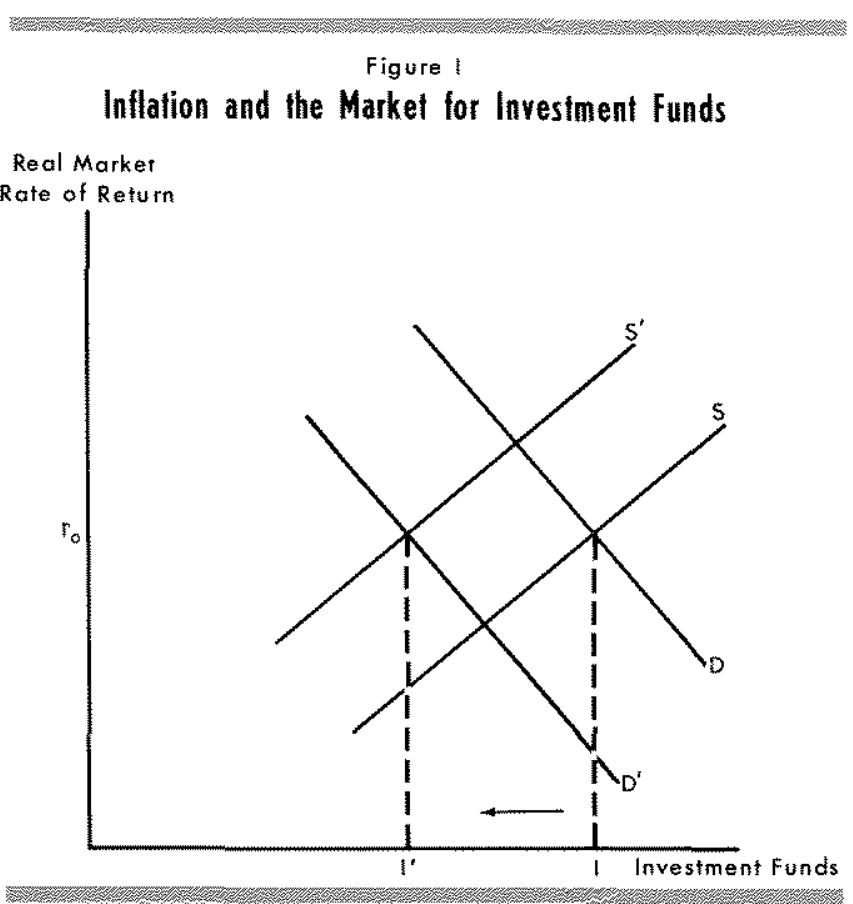

economically unfeasible due to the emergence of inflation, thereby reducing the level of investment demanded by firms..$^{14}$ In addition, the same inflation rate, operating through the personal tax system, drives up the real market yields at which investors are willing to supply funds.

The results are depicted in Figure I which shows business' demand for funds and investors' supply of funds at different real market rates. Initially the supply and demand curves are $S$ and $D$. Additional factors which affect demand or supply, including the inflation rate, are assumed to be given along the curves. Other things equal, investors will supply more funds, the greater is the real market rate of interest. Similarly, businesses demand fewer funds to invest in assets when the real market rate of interest rises. The amount of funds supplied and demanded are equal, initially, at the real market interest rate, $r_{0}$ *

For a given real market rate of interest (and cost of funds to business), an increase in the rate of inflation reduces the number of projects which businesses find attractive, thereby reducing their demand for funds. Such a shift in demand is indicated by $D^{\prime}$ in Figure $I$. At the same time, the increase in the inflation rate reduces the after-tax real rate of return on equity or bond purchases, given real market yields, reducing

\footnotetext{
1.Hai Hong, "Inflation and the Market Value of the Firm; Theory and Tests," Joumal of Findnce (September 1977), pp. 1031-48, presents supporting statistical evidence of the reduction in the value of firms in an inflationaty environment due to tax effects of historical cost depreciation.
} 
the incentives for individuals to supply funds. Such a shift in supply is indicated by the leftward movement of supply to $S^{\prime}$ in Figure I. The ultimate effect on the real market rate depends upon the change in the relative scarcity of funds in the market place. If the reduction in demand for new funds is matched by an equal reduction in the supply of funds, no change would occur in real market rates, as is indicated in the figure. However, if the supply of funds declines relative to demand, the increase in the scarcity of funds will cause a rise in real market rates.

Regardless of the net effect of inflation on real market rates of return, the analysis indicates that, as a consequence of the U.S. tax system, inflation unambiguously reduces incentives to undertake new investment projects, and therefore business investment spending declines. Such a reduction is indicated in Figure $I$ by the change in investment funds from $I$ to $I^{\prime}$.

\section{COnCHSONG}

The U.S. tax system evolved over a period of relatively minor inflation and was not designed to avoid inflation's detrimental effects on economic decisions. As inflation has trended upward and expectations of future inflation have become widely held, the U.S. tax system has had an increasingly detrimental effect on business investment.

Substantial changes in the tax system would be required to insulate investment decisions from the adverse effects of inflation. The requirements include tying the income levels for personal income tax brackets, as well as deductions and exemptions, to the rate of inflation in order to avoid the disincentives associated with progressivity of the personal income tax. In addition, the personal income tax would have to be altered so as to eliminate the taxation of inflation premiums in interest income from bonds and dividend income from stocks as well as the taxation of inflationgenerated capital gains. ${ }^{15}$ At the company level, a business would have to be allowed replacement cost depreciation rather than historical cost depreciation to avoid taxing capital as well as income.

The history of tax law alterations in the United States indicates that such a large number of major revisions in corporate and personal income tax laws is most unlikely. Nonetheless, the critically important role of business investment in providing for growth in productivity, employment, and our standard of living hangs in the balance.

Of course, there is an alternative to the massive tax reform suggested here. Fiscal and monetary policies could be adopted to reduce substantially, or even eliminate, inflation and the distortions it creates. Only a noninflationary environment is consistent with the principles of taxation and our existing tax laws.

15 Of course, firms would have to be limited to deducting only real interest expenses and not nominal interest payments to eliminate any tax advaritage which inflationinduced higher interest payments produce.

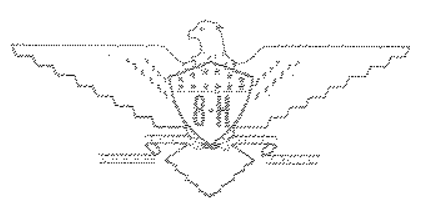

